\title{
Effects of silicon on aluminum toxicity in upland rice plants
}

\author{
Lucas Barbosa de Freitas - Dirceu Maximino Fernandes • \\ Suelen Cristina Mendonça Maia • Adalton Mazetti Fernandes
}

Received: 17 April 2017 / Accepted: 21 August 2017 / Published online: 29 August 2017

(C) Springer International Publishing AG 2017

\begin{abstract}
Aims This study aimed to determine the capacity of $\mathrm{Si}$ to mitigate $\mathrm{Al}$ toxicity in upland rice plants (Oryza sativa L.) by evaluating plant growth and the $\mathrm{Si}$ and Al uptake kinetics.

Methods Plants were grown for 40 days, after which the $\mathrm{Si}$ and $\mathrm{Al}$ uptake kinetics (Cmin, $\mathrm{Km}$ and Imax) were analyzed. Then, the shoots and roots were separated, and the dry matter, root morphology and $\mathrm{Si}$ and $\mathrm{Al}$ concentration and accumulation in the plant were evaluated.

Results Aluminum decreased plant growth and the $\mathrm{Si}$ uptake capacity by decreasing the root growth and $\mathrm{Si}$ transport system efficiency in the upland rice roots (>
\end{abstract}

L. B. de Freitas $(\bowtie)$

Faculdade La Salle, Universitária Avenue, 1000 W, Lucas do Rio Verde 78455-000, Brazil

e-mail: lucasbarbosaf@yahoo.com.br

D. M. Fernandes

College of Agricultural Sciences, Department of Soil and

Environmental Resources, São Paulo State University (UNESP),

José Barbosa de Barros Street, 1780, Botucatu 18610-307, Brazil

S. C. M. Maia

Advanced Campus Cristalina, Goiano Federal Institute (IF Goiano), Araguaia Street, P.O. Box 166, Cristalina 73850-000, Brazil

A. M. Fernandes

Center for Tropical Roots and Starches, São Paulo State University

(UNESP), José Barbosa de Barros Street, 1780,

Botucatu 18610-307, Brazil
$\mathrm{Km}$ and $>\mathrm{Cmin}$ ). Silicon mitigated $\mathrm{Al}$ toxicity in the upland rice plants by decreasing $\mathrm{Al}$ transport to the plant shoots, although it did not reduce the $\mathrm{Al}$ uptake rate (Imax). Si treatment increased the growth of upland rice plant shoots grown in the presence of $\mathrm{Al}$ without influencing the root growth. The alleviation of $\mathrm{Al}$ toxicity by $\mathrm{Si}$ is more evident in the susceptible upland rice cultivar Maravilha.

Conclusions Silicon mitigated Al toxicity in the upland rice plants by decreasing $\mathrm{Al}$ transport to the plant shoots but did not reduce the $\mathrm{Al}$ uptake rate by roots.

Keywords Uptake kinetics · Root morphology · Silicon alleviation $\cdot$ Silicon uptake
Abbreviations
C Cultivar
Cmin External concentration when net uptake is zero
DM Dry matter
Km Michaelis-Menten constant
Imax maximal transport rate

\section{Introduction}

Aluminum (Al) is toxic to plant growth and becomes a problem in acid soils; it is also a limiting factor for agricultural production. Al directly affects plant roots by decreasing and/or inhibiting root cell division (Clarkson 1965; Morimura and Matsumoto 1978), interfering with mitosis (Budikova and Durcekova 2004; 
Doncheva et al. 2005; Li et al. 2008; Yi et al. 2010) and with cell elongation, and decreasing cell wall plasticity and elasticity (Tabuchi and Matsumoto 2001; Ma et al. 2004; Zheng and Yang 2005; Horst et al. 2007). In addition, Al has negative effects on the plasma membrane, cytoskeleton, cell nucleus and apoplast (Horst et al. 2007; Yang et al. 2008; Khan et al. 2009; Panda et al. 2009; Rangel et al. 2009; Yang et al. 2011) and alters cellular calcium homeostasis (Huang et al. 1996; Rengel and Zhang 2003).

Aluminum-induced alterations to the plant cell cause plant roots grown under conditions of $\mathrm{Al}$ toxicity to become atrophied and brittle, experience fine-scale changes, and present increased cell wall rigidity and thickness, and changes in membrane transport proteins are also observed (Meharg 1993; Kochian et al. 2004; Vitorello et al. 2005; Zobel et al. 2007; Kopittke et al. 2008). Therefore, a root developed in the presence of $\mathrm{Al}$ experiences reduced growth and presents less efficient water and nutrient uptake, especially in the deeper soil layers (Mistro et al. 2001; Barceló and Poschenrieder 2002; Kochian et al. 2004; Mariano and Keltjens 2005; Olivares et al. 2009; Silva et al. 2010; Freitas et al. 2017). Furthermore, as a secondary effect, Al induces less chlorophyll production in the plant shoots and decreases the photosynthetic rate (Zhang et al. 2007; Ali et al. 2008; Aftab et al. 2010; Shen et al. 2014). These effects on roots impair plant shoot growth and grain production.

Upland rice plants are moderately tolerant to $\mathrm{Al}(\mathrm{Ma}$ et al. 2002); therefore, Brazil cultivates this type of rice in soils with low natural fertility ("Cerrado") that have high Al levels. Nevertheless, because the growth of these plants may be impaired by Al toxicity (Singh et al. 2011; Alvarez et al. 2012), mitigation techniques are required. One method of reducing the damage caused by Al to plants is the application of silicates; this approach is supported by studies that have demonstrated that silicon ( $\mathrm{Si}$ ) can alleviate the damage caused by $\mathrm{Al}$ (Hammond et al. 1995; Corrales et al. 1997; Cocker et al. 1998; Sangster and Hodson 2001; Kidd et al. 2001; Wang et al. 2004; Singh et al. 2011; Shen et al. 2014). However, the interaction between $\mathrm{Si}$ and $\mathrm{Al}$ is not well understood, and several hypotheses regarding the role of $\mathrm{Si}$ in the alleviation of Al toxicity remain inconclusive.

Silicon contributes to the alleviation of Al toxicity via reactions that occur in the soil solution as well as via plant internal mechanisms. The mitigating effect of $\mathrm{Si}$ on $\mathrm{Al}$ toxicity is related to decreasing $\mathrm{Al}$ levels in the soil solution via Al-Si complexing (Ma et al. 1997; Liang et al. 2007); furthermore, Si may reduce Al toxicity in the plant (Hodson and Evans 1995; Corrales et al. 1997; Cocker et al. 1998; Neumam and Nieden 2001; Kidd et al. 2001; Ryder et al. 2003; Wang et al. 2004; Liang et al. 2007) because accumulations of Al and $\mathrm{Si}$ in the plant are mutually exclusive, causing the plant to take up Si instead of Al (Hodson and Evans 1995). Thus, the Al tolerance of certain plant species may be associated with higher Si uptake and accumulation in the plant tissues, especially in upland rice plants, which present highly efficient Si uptake and accumulation (Ma and Yamaji 2006; Tokura et al. 2011).

Thus, studies evaluating Si and Al uptake kinetics are important for understanding the interactions of these elements in the plant and nutrient solution. The uptake efficiency of any element is influenced by its kinetic parameters (Barber 1984).

Therefore, the aim of this study was to evaluate the capacity of $\mathrm{Si}$ to mitigate $\mathrm{Al}$ toxicity in upland rice plants by evaluating the plant growth and the Si and Al uptake kinetics.

\section{Materials and methods}

The experiment was performed in a nutrient solution in a greenhouse at the Department of Soil and Environmental Resources of São Paulo State University in Botucatu, São Paulo, Brazil. The experiment was arranged in a $2 \times 5$ factorial randomized complete block design, with five replicates. The experiments included two upland rice cultivars (ANa7007, which is Al tolerant, and Maravilha, which is Al susceptible) (Freitas et al. 2016) and four $\mathrm{Si}$ and $\mathrm{Al}$ treatments (control = without $\mathrm{Si}$ and $\mathrm{Al} ;+\mathrm{Si}=$ with $\mathrm{Si}$ and without $\mathrm{Al} ;+\mathrm{Al}=$ without $\mathrm{Si}$ and with $\mathrm{Al}$; and $+\mathrm{Si}+\mathrm{Al}=$ with $\mathrm{Si}$ and $\mathrm{Al}$ ). The $\mathrm{Si}$ and $\mathrm{Al}$ concentrations in the solution were defined in preliminary studies. The Si was supplied at $1.7 \mathrm{mmol}$ $\mathrm{L}^{-1}$, and the $\mathrm{Al}$ was supplied at $1.4 \mathrm{mmol} \mathrm{L}^{-1}$. Potassium silicate was used as the Si source, with the potassium previously removed in a cationic column. The $\mathrm{Al}$ source was aluminum chloride.

To obtain plants for the experiment, seeds were germinated in a germination chamber, and after the emergence of seedlings, those with a consistent and uniform shape were selected. In total, eight seedlings were transferred to individual $4 \mathrm{~L}$ pots filled with nutrient solution. 
The nutrient solution used for plant growth contained the following (in $\mathrm{mmol} \mathrm{L}^{-1}$ ): $1.42 \mathrm{Ca}, 1.51 \mathrm{~K}, 0.33 \mathrm{Mg}$, $0.95 \mathrm{~N}^{-\mathrm{NO}_{3}}, 0.41 \mathrm{~N}^{-\mathrm{NH}_{4}}, 0.01 \mathrm{P}, 0.21 \mathrm{~S}, 0.21 \mathrm{Cl}, 0.22$ $\mathrm{Fe}, 0.009 \mathrm{Mn}, 0.008 \mathrm{~B}, 0.00076 \mathrm{Zn}$ and $0.00031 \mathrm{Cu}$. Only the $\mathrm{Si}$ and $\mathrm{Al}$ elements varied between the treatments.

In the first seven days of growth, all nutrients were used in the nutrient solution at half concentration to encourage plant adaptation, and for the next 14 days, the full nutrient concentrations were used. After this period, the Si and Al treatments were added, and the plants were grown for an additional 19 days.

Throughout the experiment, the nutrient solution was aerated and the $\mathrm{pH}$ was monitored daily and maintained at approximately $4.0( \pm 0.1)$, and $\mathrm{NaOH}\left(0.1 \mathrm{~mol} \mathrm{~L}^{-1}\right)$ and $\mathrm{HCl}\left(0.1 \mathrm{~mol} \mathrm{~L}^{-1}\right)$ were used to adjust the $\mathrm{pH}$. The nutrient solution was replaced weekly while also adding the appropriate treatments, and the amount lost to evapotranspiration was replaced daily with demineralized water.

After 40 days of growth, the Si and Al uptake kinetics of the plants were analyzed according to the Claassen and Barber (1974) method. This method allows quantification of the rate of depletion of $\mathrm{Si}$ and $\mathrm{Al}$ from solution, characterizing the $\mathrm{Si}$ and $\mathrm{Al}$ flux through the plant roots, since the plants adapt nutrient uptake kinetics to their internal nutrient status. The method uses only one plant or group of plants to obtain data over a range of $\mathrm{Si}$ and $\mathrm{Al}$ concentrations in solution and measures the concentration below which net influx of $\mathrm{Si}$ and $\mathrm{Al}$ through roots ceases $(\mathrm{Cmin})$. This method thus allows the identification of the Imax of $\mathrm{Si}$ and $\mathrm{Al}$, i.e., the maximum transport rate or maximum influx rate of $\mathrm{Si}$ and $\mathrm{Al}$; the Michaelis-Menten constant $(\mathrm{Km})$ that represents the $\mathrm{Si}$ and $\mathrm{Al}$ concentrations in solution that produce $50 \%$ of Imax; and the $\mathrm{Cmin}$, which represents the $\mathrm{Si}$ and $\mathrm{Al}$ concentrations in solution at which net influx is zero.

The nutrient solution for all of the treatments was replaced by the same solution without $\mathrm{Si}$ and $\mathrm{Al}$, and the plants remained in this solution for $48 \mathrm{~h}$ to increase the plant uptake ability of the studied elements. Then, the nutrient solution was replaced again, and $0.11 \mathrm{mmol} \mathrm{L}^{-1}$ $\mathrm{Si}$ and $0.19 \mathrm{mmol} \mathrm{L}^{-1} \mathrm{Al}$ were added to all of the treatments. The plants remained under these conditions for one hour, until uptake was stabilized in the roots. Then, the nutrient solution for all of the treatments was replaced again with a solution identical to the previous solution with $\mathrm{Al}$ and $\mathrm{Si}$, and sampling was initiated.
Samples $(10 \mathrm{~mL}$ each) of the solution were collected every $30 \mathrm{~min}$ in the first six hours, every $60 \mathrm{~min}$ in the six subsequent hours, and once in the final $24 \mathrm{~h}$. Then, four additional samples were collected every $12 \mathrm{~h}$ to obtain the Cmin. Throughout the sampling period, the pot volume was kept constant by the addition of demineralized water. The temperature of the nutrient solution throughout the sampling averaged $22.6{ }^{\circ} \mathrm{C}$, and the solution $\mathrm{pH}$ was monitored every $60 \mathrm{~min}$ and maintained at approximately $4.0( \pm 0.1)$.

The $\mathrm{Si}$ and $\mathrm{Al}$ concentrations in the collected samples were determined by Inductively Coupled Plasma (ICP). The Km and Imax values were estimated based on the $\mathrm{Si}$ and $\mathrm{Al}$ concentrations in the samples and the root dry matter values, using the software CinéticaWin - the Windows version of Cinética 1.2 (Ruiz and Fernandes Filho 1992). In all treatments, the Cmin values for Si and Al were obtained when the $\mathrm{Si}$ and $\mathrm{Al}$ concentrations in the solution remained constant (external concentration when net uptake is zero). Thus, in all treatments, the $\mathrm{Al} \mathrm{Cmin} \mathrm{was} \mathrm{con-}$ sidered to be the value obtained at $24 \mathrm{~h}$. The values of $\mathrm{Si} \mathrm{Cmin}$ in the control and +Si treatments were obtained at $24 \mathrm{~h}$, but in the treatments $+\mathrm{Al}$ and $+\mathrm{Si}+\mathrm{Al}$, the $\mathrm{Si}$ Cmin was obtained at $48 \mathrm{~h}$.

After the exhaust solution was collected, the plant shoots and roots were separated. The length, surface area and diameter of the roots were determined using a scanner linked to a desktop computer running WinRhizo $3.8 \mathrm{~b}$ software (Regent Instruments, Inc., Quebec, Canada) following the methods of Tennant (1975). The root length was also quantified separately for the fine roots (diameter $<0.5 \mathrm{~mm}$ ), medium roots (diameter between 0.5 to $1.00 \mathrm{~mm}$ ) and thick roots (diameter $>1.00 \mathrm{~mm}$ ). Then, the shoot and root samples were dried in a forcedair circulation oven $\left(65^{\circ} \mathrm{C}\right)$ to a constant weight, and the dry matter (DM) content was determined. The samples were ground and the $\mathrm{Si}$ and $\mathrm{Al}$ concentrations were determined according to the method of Elliott and Snyder (1991) as adapted by Korndörfer et al. (1999) and Malavolta et al. (1997), respectively. The DM and the $\mathrm{Si}$ and $\mathrm{Al}$ concentrations in both parts of the plant were used to calculate the accumulated $\mathrm{Si}$ and $\mathrm{Al}$ quantities. The whole-plant accumulated $\mathrm{Si}$ and $\mathrm{Al}$ quantities were obtained from the sum of the root and shoot accumulations.

The data were subjected to analysis of variance. The treatment averages were obtained by comparing the $\mathrm{t}$ test results (LSD) at the 5\% probability level. 


\section{Results}

The shoot, root and whole plant DM of the upland rice plants were affected by the treatments and by the interactions between the cultivar (C) and the $\mathrm{Si}$ and $\mathrm{Al}$ supply ( $\mathrm{Si}-\mathrm{Al}$ ) (Table 1). The shoot DM of the cultivar ANa7007 (Al tolerant) was higher than that of the cultivar Maravilha only in the treatment that received $\mathrm{Al}$ and Si. For both cultivars, the Si treatments with and without $\mathrm{Al}$ provided shoot $\mathrm{DM}$ similar to that in the control treatment (without $\mathrm{Si}$ and $\mathrm{Al}$ ); however, in the treatment without $\mathrm{Si}, \mathrm{Al}$ reduced the shoot $\mathrm{DM}$ by $13 \%$ and $10 \%$ for ANa7007 and Maravilha, respectively (Table 1).

In the isolated $\mathrm{Si}$ treatment, the root $\mathrm{DM}$ of the cultivar ANa7007 (Al tolerant) was higher than that of Maravilha (Al susceptible), whereas in the treatments with Al, the root DM of ANa7007 was lower than that of Maravilha, independent of the Si supply (Table 1). However, in both cultivars, the root DM did not increase under the Si treatments (Table 1).

The whole-plant DM was only higher in ANa7007 than in Maravilha in the isolated Si treatment (Table 1). However, although plant growth decreased in both

Table 1 Dry matter accumulation in the plant tissues and root system parameters of upland rice cultivars grown under different conditions of silicon ( $\mathrm{Si}$ ) and aluminum (Al) inclusion in a nutrient solution. The results of an analysis of variance are shown

\begin{tabular}{|c|c|c|c|c|c|c|c|}
\hline \multirow[t]{2}{*}{ Cultivar } & \multicolumn{4}{|c|}{$\mathrm{Si}$ and $\mathrm{Al}$ conditions } & \multicolumn{3}{|c|}{ Source of variation } \\
\hline & Control & $+\mathrm{Si}$ & $+\mathrm{Al}$ & $+\mathrm{Si}+\mathrm{Al}$ & $\mathrm{C}^{(1)}$ & $\mathrm{Si}-\mathrm{Al}$ & $\mathrm{C} \times \mathrm{Si}-\mathrm{Al}$ \\
\hline \multicolumn{8}{|c|}{ Shoot dry matter $\left(\mathrm{g} \mathrm{pot}^{-1}\right)$} \\
\hline $\begin{array}{l}\text { Maravilha } \\
\text { ANa7007 }\end{array}$ & $\begin{array}{l}11.1 \mathrm{ab} \\
11.7 \mathrm{bc}\end{array}$ & $\begin{array}{l}11.7 \mathrm{a} \\
12.5 \mathrm{ab}\end{array}$ & $\begin{array}{l}10.2 \mathrm{~b} \\
11.02 \mathrm{c}\end{array}$ & $\begin{array}{l}11.3^{\dagger} \mathrm{a} \\
12.6 \mathrm{a}\end{array}$ & $<0.001$ & $<0.001$ & 0.008 \\
\hline \multicolumn{8}{|c|}{ Root dry matter $\left(\mathrm{g} \mathrm{pot}^{-1}\right)$} \\
\hline $\begin{array}{l}\text { Maravilha } \\
\text { ANa7007 }\end{array}$ & $\begin{array}{l}5.8 \mathrm{a} \\
5.9 \mathrm{a}\end{array}$ & $\begin{array}{l}5.6^{\dagger} \mathrm{a} \\
6.2 \mathrm{a}\end{array}$ & $\begin{array}{l}3.9^{\dagger} \mathrm{b} \\
2.9 \mathrm{~b}\end{array}$ & $\begin{array}{l}3.9^{\dagger} \mathrm{b} \\
2.7 \mathrm{~b}\end{array}$ & $<0.001$ & $<0.001$ & $<0.001$ \\
\hline \multicolumn{8}{|c|}{ Whole-plant dry matter $\left(\mathrm{g} \mathrm{pot}^{-1}\right)$} \\
\hline $\begin{array}{l}\text { Maravilha } \\
\text { ANa7007 }\end{array}$ & $\begin{array}{l}16.9 \mathrm{a} \\
17.6 \mathrm{a}\end{array}$ & $\begin{array}{l}17.3^{\dagger} \mathrm{a} \\
18.8 \mathrm{a}\end{array}$ & $\begin{array}{l}14.2 \mathrm{~b} \\
13.9 \mathrm{c}\end{array}$ & $\begin{array}{l}15.2 \mathrm{~b} \\
15.4 \mathrm{~b}\end{array}$ & 0.086 & $<0.001$ & 0.018 \\
\hline \multicolumn{8}{|c|}{ Root length (m pot $\left.{ }^{-1}\right)$} \\
\hline $\begin{array}{l}\text { Maravilha } \\
\text { ANa7007 }\end{array}$ & $\begin{array}{l}1090 \mathrm{a} \\
1187 \mathrm{~b}\end{array}$ & $\begin{array}{l}1068^{\dagger} \mathrm{a} \\
1334 \mathrm{a}\end{array}$ & $\begin{array}{l}375 b \\
360 \mathrm{c}\end{array}$ & $\begin{array}{l}325 \mathrm{~b} \\
354 \mathrm{c}\end{array}$ & $<0.001$ & $<0.001$ & 0.002 \\
\hline \multicolumn{8}{|c|}{ Root surface $\left(\mathrm{cm}^{2}\right.$ pot $\left.^{-1}\right)$} \\
\hline $\begin{array}{l}\text { Maravilha } \\
\text { ANa7007 }\end{array}$ & $\begin{array}{l}9395 a \\
9799 a\end{array}$ & $\begin{array}{l}8935^{\dagger} \mathrm{a} \\
9706 \mathrm{a}\end{array}$ & $\begin{array}{l}3916^{\dagger} \mathrm{b} \\
2872 \mathrm{~b}\end{array}$ & $\begin{array}{l}3422 b \\
2947 b\end{array}$ & 0.598 & $<0.001$ & 0.001 \\
\hline \multicolumn{8}{|c|}{ Root diameter (mm) } \\
\hline $\begin{array}{l}\text { Maravilha } \\
\text { ANa7007 }\end{array}$ & $\begin{array}{l}0.28 \mathrm{~b} \\
0.26 \mathrm{a}\end{array}$ & $\begin{array}{l}0.27 b \\
0.24 a\end{array}$ & $\begin{array}{l}0.33^{\dagger} \mathrm{a} \\
0.27 \mathrm{a}\end{array}$ & $\begin{array}{l}0.35^{\dagger} \mathrm{a} \\
0.28 \mathrm{a}\end{array}$ & $<0.001$ & $<0.001$ & 0.008 \\
\hline \multicolumn{8}{|c|}{ Root length $(<0.5 \mathrm{~mm})\left(\mathrm{m} \mathrm{pot}^{-1}\right)$} \\
\hline $\begin{array}{l}\text { Maravilha } \\
\text { ANa7007 }\end{array}$ & $\begin{array}{l}960 a \\
1012 b\end{array}$ & $\begin{array}{l}909^{\dagger} \mathrm{a} \\
1165 \mathrm{a}\end{array}$ & $\begin{array}{l}278 b \\
300 \mathrm{c}\end{array}$ & $\begin{array}{l}259 b \\
275 c\end{array}$ & $<0.001$ & $<0.001$ & $<0.001$ \\
\hline \multicolumn{8}{|c|}{ Root length $(0.5-1.0 \mathrm{~mm})\left(\mathrm{m} \mathrm{pot}^{-1}\right)$} \\
\hline $\begin{array}{l}\text { Maravilha } \\
\text { ANa7007 }\end{array}$ & $\begin{array}{l}83^{\dagger} \mathrm{a} \\
116 \mathrm{a}\end{array}$ & $\begin{array}{l}82^{\dagger} \mathrm{a} \\
112 \mathrm{a}\end{array}$ & $\begin{array}{l}58 \mathrm{~b} \\
51 \mathrm{~b}\end{array}$ & $\begin{array}{l}50 \mathrm{~b} \\
53 \mathrm{~b}\end{array}$ & $<0.001$ & $<0.001$ & $<0.001$ \\
\hline Root length ( & ) $\left(\mathrm{m}\right.$ pot $^{-}$ & & & & & & \\
\hline $\begin{array}{l}\text { Maravilha } \\
\text { ANa7007 }\end{array}$ & $\begin{array}{l}46^{\dagger} \mathrm{a} \\
58 \mathrm{a}\end{array}$ & $\begin{array}{l}47^{\dagger} \mathrm{a} \\
57 \mathrm{a}\end{array}$ & $\begin{array}{l}14.0^{\dagger} \mathrm{b} \\
9.1 \mathrm{~b}\end{array}$ & $\begin{array}{l}16.4^{\dagger} \mathrm{b} \\
8.8 \mathrm{~b}\end{array}$ & 0.013 & $<0.001$ & $<0.001$ \\
\hline
\end{tabular}

\footnotetext{
${ }^{\dagger}$ Significant difference between the upland rice cultivars under the same Si and Al supply condition; mean values followed by the same letters in the rows are not significantly different at $P \leq 0.05$ according to the LSD test

(1) $\mathrm{C}$, cultivar; $\mathrm{Si}-\mathrm{Al}, \mathrm{Si}$ and $\mathrm{Al}$ supply conditions; $\mathrm{C} \times \mathrm{Si}-\mathrm{Al}$, interactions of cultivar $\times \mathrm{Si}$ and $\mathrm{Al}$ supply conditions
} 
cultivars with the addition of $\mathrm{Al}$, in the treatment with the combination of $\mathrm{Al}$ and $\mathrm{Si}$, the whole-plant $\mathrm{DM}$ of ANa7007 was higher than was observed with the Alonly treatment.

The root morphology parameters were influenced by the main treatment factors and the $\mathrm{C} x \mathrm{Si}$-Al interactions (Table 1). In the Si-only treatment, the cultivar ANa7007 (Al tolerant) showed a greater root length and surface area than the Al-susceptible cultivar. However, the root surface area of the cultivar Maravilha (Al susceptible) under the $\mathrm{Al}$ treatment was greater than that of ANa7007 (Al tolerant). The root length and surface area of both cultivars decreased in the presence of $\mathrm{Al}$, independent of the presence of Si (Table 1). Moreover, Al increased the root diameter only in the cultivar Maravilha, which is susceptible to Al toxicity.

In the Si-only treatment, the lengths of the fine and medium roots were greater in ANa7007 than in Maravilha, whereas no differences in the lengths of the fine and medium roots were observed between the cultivars in the $\mathrm{Al}$ treatments (Table 1). The root diameter of ANa7007 was not significantly affected by $\mathrm{Al}$, and because this cultivar is $\mathrm{Al}$ tolerant, it exhibited shorter thick roots than did the cultivar Maravilha in the $\mathrm{Al}$ treatments (Table 1).

Silicon accumulated in the upland rice plant shoots to higher levels in the treatments that received $\mathrm{Si}$, regardless of the presence of $\mathrm{Al}$ in the solution (Table 2). In the roots, the Si concentration and accumulation were affected by the $\mathrm{C} \times \mathrm{Si}-\mathrm{Al}$ interactions. In both cultivars, the root $\mathrm{Si}$ concentrations were higher when $\mathrm{Si}$ and $\mathrm{Al}$ were supplied together. In the Si and Al treatments, root accumulation of $\mathrm{Si}$ was lower in $\mathrm{ANa} 7007$ than in Maravilha; however, in both cultivars, root Si accumulation in the presence of $\mathrm{Al}$ was lower than in the control treatment. In the whole plant, $\mathrm{Si}$ accumulation did not differ between the cultivars, with more Si accumulating in the treatments that included $\mathrm{Si}$, regardless of the presence of $\mathrm{Al}$ in the solution.

The $\mathrm{Al}$ concentrations in both the shoots and roots and $\mathrm{Al}$ accumulation in the roots were affected by the $\mathrm{C}$ $\mathrm{x} \mathrm{Si-Al}$ interactions; however, $\mathrm{Al}$ accumulation in the shoots was only affected by the different $\mathrm{Si}$ and $\mathrm{Al}$ treatments (Table 2). In the Al-only treatments, the Altolerant cultivar (ANa7007) showed lower Al concentrations in the shoots than the susceptible cultivar (Maravilha) but did not exhibit lower $\mathrm{Al}$ accumulation. However, in both cultivars, the $\mathrm{Al}$ concentrations in the shoots were only higher under treatment with $\mathrm{Al}$ alone, whereas in the combined $\mathrm{Si}$ and $\mathrm{Al}$ treatments, the shoot Al concentration decreased. Although Si decreased the shoot Al concentrations in both cultivars, only Maravilha exhibited decreased $\mathrm{Al}$ accumulation in the shoots under the $\mathrm{Al}$ and $\mathrm{Si}$ treatments.

Independent of the $\mathrm{Si}$ supply, the presence of $\mathrm{Al}$ in the solution caused ANa7007 (Al tolerant) to exhibit higher root $\mathrm{Al}$ concentrations, although it accumulated less $\mathrm{Al}$ in the roots than the susceptible cultivar because of its lower root DM production (Tables 1 and 2).

In the whole plant, the accumulation of $\mathrm{Al}$ was influenced by the $\mathrm{C}$ x Si-Al interactions (Table 2). The Altolerant cultivar (ANa7007) only accumulated less $\mathrm{Al}$ than the susceptible cultivar (Maravilha) under treatment with $\mathrm{Al}$ alone, whereas supplying $\mathrm{Si}$ in the solution only decreased the accumulation of $\mathrm{Al}$ in the susceptible cultivar. In the Al-tolerant cultivar, the presence of $\mathrm{Si}$ in the solution did not decrease the accumulation of $\mathrm{Al}$ in the shoots, roots or whole plant. However, in the presence of Al, the addition of Si increased the shoot DM of this cultivar (Tables 1 and 2).

In both cultivars, Si was taken up from the solution at a higher rate in the treatments without $\mathrm{Al}$, and after 10 $12 \mathrm{~h}$, the Si uptake rate remained constant, with $\mathrm{Si}$ concentrations below $20 \mu \mathrm{mol} \mathrm{L}{ }^{-1}$ being observed in the solution (Fig. 1a and b). By contrast, in the treatments with $\mathrm{Al}$, although the rate of $\mathrm{Si}$ uptake was reduced, after $10 \mathrm{~h}$, the concentration in the solution was higher than $60 \mu \mathrm{mol} \mathrm{L}{ }^{-1}$.

The kinetic parameters of Si uptake were affected by the $\mathrm{C} \times \mathrm{Si}-\mathrm{Al}$ interactions (Table 3). In the control and combined Si-Al treatments, ANa7007 exhibited higher $\mathrm{Si}$ Imax values than Maravilha. For both cultivars, the $\mathrm{Si}$ Imax in the control treatment was 1.5 times higher on average than in the Si-only treatment and 2.2 times higher than in the treatments with $\mathrm{Al}$.

In the presence of $\mathrm{Al}$, the $\mathrm{Si} \mathrm{Km}$ and $\mathrm{Cmin}$ values differed between the cultivars, with higher values being observed in ANa7007 under the Al-only treatment and in Maravilha under combined $\mathrm{Si}$ and $\mathrm{Al}$ treatment (Table 3).

The rate of $\mathrm{Al}$ uptake from the solution was low in the first $10 \mathrm{~h}$ and then remained relatively stable (Fig. 1). The kinetic parameters of Al uptake were affected by the $\mathrm{Cx}$ Si-Al interactions (Table 3). The cultivar Maravilha (Al susceptible) exhibited a higher Al Imax than ANa7007 in the treatments without Al during the initial plant growth stage. However, in the Al-susceptible cultivar, Al Imax was lower in the control treatment and in 
Table 2 Concentration and accumulation of silicon ( $\mathrm{Si}$ ) and aluminum (Al) in plant tissues and whole plants of upland rice cultivars grown under different conditions of silicon $(\mathrm{Si})$ and aluminum $(\mathrm{Al})$ inclusion in a nutrient solution. The results of an analysis of variance are shown

\begin{tabular}{|c|c|c|c|c|c|c|c|}
\hline \multirow[t]{2}{*}{ Cultivar } & \multicolumn{4}{|c|}{$\mathrm{Si}$ and $\mathrm{Al}$ conditions } & \multicolumn{3}{|c|}{ Source of variation } \\
\hline & Control & $+\mathrm{Si}$ & $+\mathrm{Al}$ & $+\mathrm{Si}+\mathrm{Al}$ & $C^{(1)}$ & $\mathrm{Si}-\mathrm{Al}$ & $\mathrm{C} \times \mathrm{Si}-\mathrm{Al}$ \\
\hline \multicolumn{8}{|c|}{ Shoot $\mathrm{Si}$ concentration $\left(\mathrm{g} \mathrm{kg}^{-1}\right)$} \\
\hline Maravilha & $8.9 \mathrm{~b}$ & $36.9 \mathrm{a}$ & $9.3 \mathrm{~b}$ & $38.1 \mathrm{a}$ & \multirow[t]{2}{*}{0.862} & \multirow[t]{2}{*}{$<0.001$} & \multirow[t]{2}{*}{0.996} \\
\hline ANa7007 & $8.9 \mathrm{~b}$ & $37.0 \mathrm{a}$ & $9.0 \mathrm{~b}$ & $37.7 \mathrm{a}$ & & & \\
\hline \multicolumn{8}{|c|}{ Root Si concentration $\left(\mathrm{g} \mathrm{kg}^{-1}\right)$} \\
\hline Maravilha & $4.7^{\dagger} \mathrm{b}$ & $5.0^{\dagger} \mathrm{b}$ & $4.3 b$ & $6.2^{\dagger} \mathrm{a}$ & \multirow[t]{2}{*}{0.017} & \multirow[t]{2}{*}{$<0.001$} & \multirow[t]{2}{*}{0.008} \\
\hline ANa7007 & $4.0 \mathrm{~b}$ & $4.2 \mathrm{~b}$ & $5.0 \mathrm{a}$ & $5.3 \mathrm{a}$ & & & \\
\hline \multicolumn{8}{|c|}{ Shoot Si accumulation $\left(\mathrm{mg} \mathrm{pot}{ }^{-1}\right)$} \\
\hline Maravilha & $102 b$ & $435 a$ & $94 b$ & $444 a$ & \multirow[t]{2}{*}{0.041} & \multirow[t]{2}{*}{$<0.001$} & \multirow[t]{2}{*}{0.537} \\
\hline ANa7007 & $112 b$ & $472 \mathrm{a}$ & $101 b$ & $493 a$ & & & \\
\hline \multicolumn{8}{|c|}{ Root Si accumulation (mg pot ${ }^{-1}$ ) } \\
\hline Maravilha & $29 a$ & $28 \mathrm{ab}$ & $17 \mathrm{c}$ & $25^{\dagger} \mathrm{b}$ & \multirow[t]{2}{*}{$<0.001$} & \multirow[t]{2}{*}{$<0.001$} & \multirow[t]{2}{*}{0.008} \\
\hline ANa7007 & $26 a$ & $27 \mathrm{a}$ & $15 b$ & $15 \mathrm{~b}$ & & & \\
\hline \multicolumn{8}{|c|}{ Whole-plant Si accum. $\left(\mathrm{mg} \mathrm{pot}^{-1}\right)$} \\
\hline Maravilha & $132 b$ & $462 \mathrm{a}$ & $112 b$ & $469 a$ & \multirow[t]{2}{*}{0.076} & \multirow[t]{2}{*}{$<0.001$} & \multirow[t]{2}{*}{0.603} \\
\hline ANa7007 & $138 b$ & $499 a$ & $116 b$ & $508 \mathrm{a}$ & & & \\
\hline \multicolumn{8}{|c|}{ Shoot $\mathrm{Al}$ concentration $\left(\mathrm{g} \mathrm{kg}^{-1}\right)$} \\
\hline Maravilha & $0.06 \mathrm{c}$ & $0.08 \mathrm{c}$ & $0.41^{\dagger} \mathrm{a}$ & $0.29 b$ & \multirow[t]{2}{*}{0.013} & \multirow[t]{2}{*}{$<0.001$} & \multirow[t]{2}{*}{0.024} \\
\hline ANa7007 & $0.07 \mathrm{c}$ & $0.05 \mathrm{c}$ & $0.34 \mathrm{a}$ & $0.28 b$ & & & \\
\hline \multicolumn{8}{|c|}{ Root $\mathrm{Al}$ concentration $\left(\mathrm{g} \mathrm{kg}^{-1}\right)$} \\
\hline Maravilha & $0.26 \mathrm{~b}$ & $0.28 \mathrm{~b}$ & $2.06^{\dagger} \mathrm{a}$ & $1.92^{\dagger} \mathrm{a}$ & \multirow[t]{2}{*}{0.002} & $<0.001$ & 0.006 \\
\hline ANa7007 & $0.28 \mathrm{~b}$ & $0.25 b$ & $2.28 \mathrm{a}$ & $2.43 \mathrm{a}$ & & & \\
\hline Shoot Al accl & $\mathrm{n}(\mathrm{mg}$ po & & & & & & \\
\hline Maravilha & $0.72 \mathrm{c}$ & $0.98 \mathrm{c}$ & $4.22 \mathrm{a}$ & $3.46 \mathrm{~b}$ & 0.812 & $<0.001$ & 0.214 \\
\hline ANa7007 & $0.97 \mathrm{~b}$ & $0.67 \mathrm{~b}$ & $3.86 \mathrm{a}$ & $3.74 \mathrm{a}$ & & & \\
\hline Root $\mathrm{Al}$ accul & (mg pot & & & & & & \\
\hline Maravilha & $1.70 \mathrm{~b}$ & $1.58 \mathrm{~b}$ & $8.21^{\dagger} \mathrm{a}$ & $7.86^{\dagger} \mathrm{a}$ & 0.001 & $<0.001$ & 0.003 \\
\hline ANa7007 & $1.84 \mathrm{~b}$ & $1.62 \mathrm{~b}$ & $6.61 \mathrm{a}$ & $6.85 \mathrm{a}$ & & & \\
\hline Whole-plant & . $(\mathrm{mg}$ po & & & & & & \\
\hline Maravilha & $2.42 \mathrm{c}$ & $2.56 \mathrm{c}$ & $12.44^{\dagger} \mathrm{a}$ & $11.33 \mathrm{~b}$ & 0.003 & $<0.001$ & 0.002 \\
\hline ANa7007 & $2.81 \mathrm{~b}$ & $2.30 \mathrm{~b}$ & $10.48 \mathrm{a}$ & $10.59 a$ & & & \\
\hline
\end{tabular}

${ }^{\dagger}$ Significant difference between the upland rice cultivars under the same Si and Al supply condition; mean values followed by the same letters in the rows are not significantly different at $P \leq 0.05$ according to the LSD test

(1) $\mathrm{C}$, cultivar; $\mathrm{Si}-\mathrm{Al}, \mathrm{Si}$ and $\mathrm{Al}$ supply conditions; $\mathrm{C} \times \mathrm{Si}-\mathrm{Al}$, interactions of cultivar $\times \mathrm{Si}$ and $\mathrm{Al}$ supply conditions

the treatments with $\mathrm{Al}$ than in the Si-only treatment, regardless of the presence of $\mathrm{Si}$ in the combined $\mathrm{Si}-\mathrm{Al}$ treatment. In the Al-tolerant cultivar, the Al Imax was only reduced in the control treatment.

In the control treatment, the $\mathrm{Al} \mathrm{Km}$ and Cmin values were lower in ANa7007 than in Maravilha. Under treatment with $\mathrm{Si}$ or $\mathrm{Al}$ alone or with the combination of $\mathrm{Si}$ and $\mathrm{Al}$, the $\mathrm{Km}$ values did not differ markedly between the cultivars, and in the Al-tolerant cultivar, the $\mathrm{Al} \mathrm{Km}$ was lower in the control treatment than in the Si-only or combined $\mathrm{Si}$ and $\mathrm{Al}$ treatments. In the susceptible cultivar Maravilha, the Cmin was lower in the Si-only treatment and higher in the Al-only and combined Si-Al treatments; however, both cultivars showed increased $\mathrm{Al} \mathrm{Cmin} \mathrm{in} \mathrm{the} \mathrm{treatments} \mathrm{that} \mathrm{included} \mathrm{Al}$ during the initial growth stage.

\section{Discussion}

The higher shoot DM production observed in the $\mathrm{Si}-\mathrm{Al}$ treatment compared with the treatment with $\mathrm{Al}$ alone 

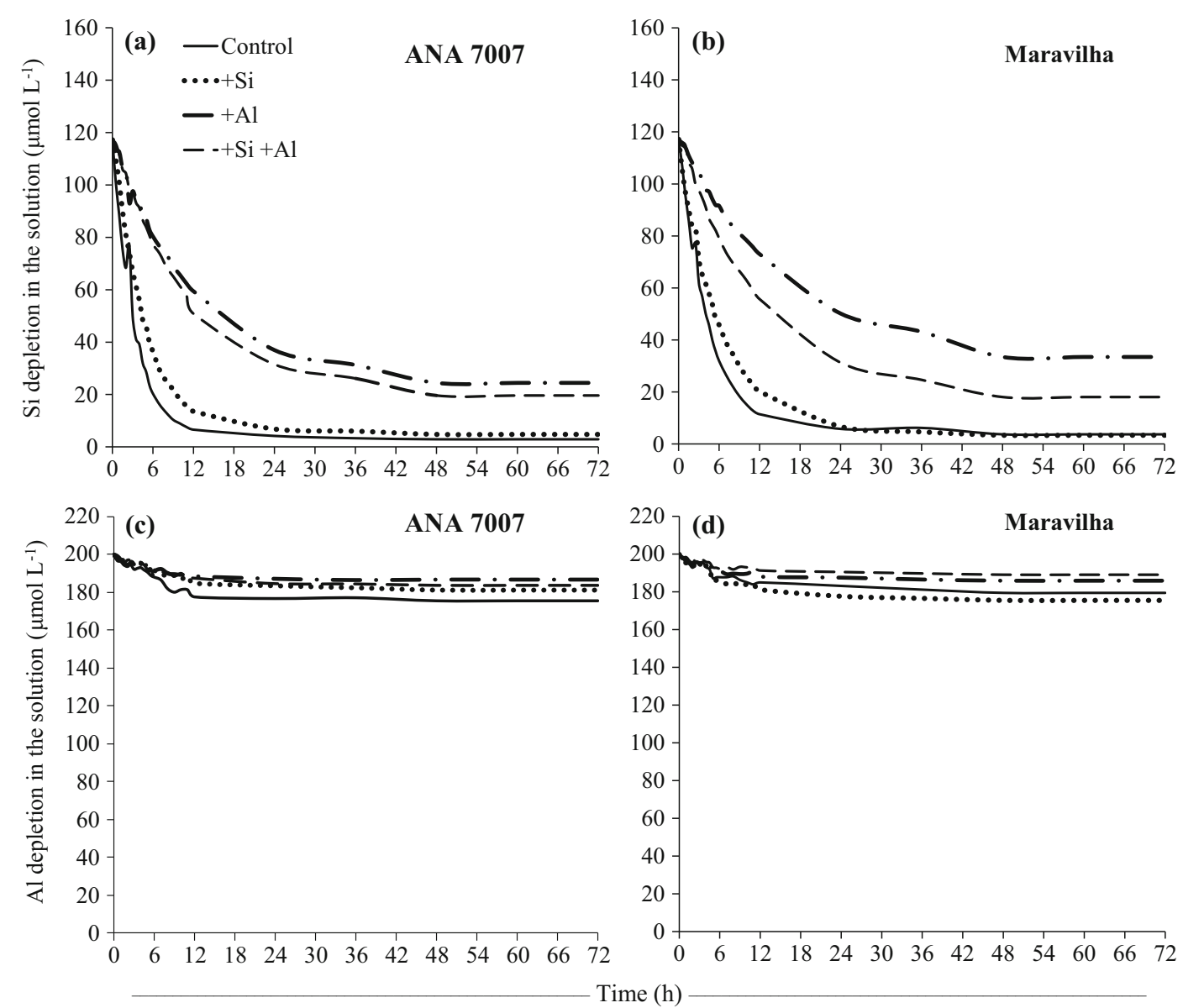

Fig. 1 Si and Al depletion in nutrient solution by upland rice cultivars ANa7007 (a and $\mathbf{c}$ ) and Maravilha (b and d) grown under different conditions of silicon $(\mathrm{Si})$ and aluminum $(\mathrm{Al})$ inclusion in a nutrient solution

(without $\mathrm{Si}$ ) and the similar DM production between the $\mathrm{Si}-\mathrm{Al}$ and control treatments indicate that $\mathrm{Si}$ mitigated Al toxicity and increased and/or maintained shoot DM production. Regarding root DM, the higher value recorded in the Al-susceptible cultivar than in the Altolerant cultivar occurred due to greater root damage in the Al-susceptible cultivar, which presented thicker, heavier roots (Table 1) because Al toxicity induces an increase in root thickness (Zobel et al. 2007). In general, Si promoted increased growth only in the shoots of the plants, especially under $\mathrm{Al}$ stress conditions, resulting in higher whole-plant DM production. Other studies (e.g., in peanut (Shen et al. 2014) and rice plants (Singh et al. 2011)) also demonstrated that for plants grown in the presence of $\mathrm{Al}, \mathrm{Si}$ increases the shoot growth.

The decrease in the DM shoot and root production in the Al treatments, in addition to being directly influenced by the Al toxic activity, can also suffer from the influence of interactions of $\mathrm{Al}$ and $\mathrm{P}$ in the nutrient solution and inside the plant, decreasing the use of this nutrient by the plant (Gaume et al. 2001; Liao et al. 2006).

The greater root length and surface area observed in the Si-only treatment of the Al-tolerant cultivar occurred because there is an increase in root production (root DM) (Table 1). On the other hand, the root surface area of the Al-susceptible cultivar was greater than that of the Al-tolerant cultivar because the roots of the susceptible cultivar, Maravilha, increased in diameter under Al toxicity, whereas this did not occur in the Al-tolerant cultivar (Table 1).

The decreases in the root length and surface area of both cultivars in the presence of $\mathrm{Al}$ demonstrate that $\mathrm{Si}$ did not decrease the stress caused by $\mathrm{Al}$ in the roots, where the primary toxic action of Al occurs (Zhang et al. 2007). Furthermore, Al increased root diameter only in 
Table 3 Kinetic parameters of silicon ( $\mathrm{Si}$ ) and aluminum (Al) uptake by upland rice cultivars grown under different conditions of silicon (Si) and aluminum (Al) inclusion in a nutrient solution. The results of an analysis of variance are shown

\begin{tabular}{|c|c|c|c|c|c|c|c|}
\hline \multirow[t]{2}{*}{ Cultivar } & \multicolumn{4}{|c|}{$\mathrm{Si}$ and $\mathrm{Al}$ conditions } & \multicolumn{3}{|c|}{ Source of variation } \\
\hline & Control & $+\mathrm{Si}$ & $+\mathrm{Al}$ & $+\mathrm{Si}+\mathrm{Al}$ & $C^{(1)}$ & $\mathrm{Si}-\mathrm{Al}$ & $\mathrm{C} \times \mathrm{Si}-\mathrm{Al}$ \\
\hline \multicolumn{8}{|c|}{$\mathrm{Si}-\operatorname{Imax}\left(\mu \mathrm{mol} \mathrm{cm} \mathrm{c}^{-2} \mathrm{~h}^{-1} 10^{-3}\right)$} \\
\hline $\begin{array}{l}\text { Maravilha } \\
\text { ANa7007 }\end{array}$ & $\begin{array}{l}13.7^{\dagger} \mathrm{a} \\
18.1 \mathrm{a}\end{array}$ & $\begin{array}{l}10.9 b \\
10.7 b\end{array}$ & $\begin{array}{l}7.1 \mathrm{c} \\
8.8 \mathrm{bc}\end{array}$ & $\begin{array}{l}4.6^{\dagger} \mathrm{d} \\
8.2 \mathrm{c}\end{array}$ & $<0.001$ & $<0.001$ & 0.019 \\
\hline \multicolumn{8}{|c|}{$\mathrm{Si}-\mathrm{Km}\left(\mu \mathrm{mol} \mathrm{L}{ }^{-1}\right)$} \\
\hline $\begin{array}{l}\text { Maravilha } \\
\text { ANa7007 }\end{array}$ & $\begin{array}{l}40 \mathrm{c} \\
37 \mathrm{c}\end{array}$ & $\begin{array}{l}39 c \\
40 c\end{array}$ & $\begin{array}{l}53^{\dagger} \mathrm{b} \\
58 \mathrm{a}\end{array}$ & $\begin{array}{l}63^{\dagger} \mathrm{a} \\
52 \mathrm{~b}\end{array}$ & 0.143 & $<0.001$ & $<0.001$ \\
\hline \multicolumn{8}{|c|}{$\mathrm{Si}-\mathrm{Cmin}\left(\mu \mathrm{mol} \mathrm{L}{ }^{-1}\right)$} \\
\hline $\begin{array}{l}\text { Maravilha } \\
\text { ANa7007 }\end{array}$ & $\begin{array}{l}5.2 \mathrm{c} \\
3.4 \mathrm{~d}\end{array}$ & $\begin{array}{l}4.9 \mathrm{c} \\
5.8 \mathrm{c}\end{array}$ & $\begin{array}{l}24.6^{\dagger} \mathrm{b} \\
34.9 \mathrm{a}\end{array}$ & $\begin{array}{l}41.8^{\dagger} \mathrm{a} \\
25.7 \mathrm{~b}\end{array}$ & 0.002 & $<0.001$ & $<0.001$ \\
\hline \multicolumn{8}{|c|}{$\mathrm{Al}-\operatorname{Imax}\left(\mu \mathrm{mol} \mathrm{cm}{ }^{-2} \mathrm{~h}^{-1} 10^{-3}\right)$} \\
\hline $\begin{array}{l}\text { Maravilha } \\
\text { ANa7007 }\end{array}$ & $\begin{array}{l}3.0^{\dagger} \mathrm{b} \\
1.5 \mathrm{~b}\end{array}$ & $\begin{array}{l}3.9^{\dagger} \mathrm{a} \\
2.8 \mathrm{a}\end{array}$ & $\begin{array}{l}2.8 \mathrm{~b} \\
3.0 \mathrm{a}\end{array}$ & $\begin{array}{l}2.6 \mathrm{~b} \\
3.2 \mathrm{a}\end{array}$ & 0.040 & 0.007 & 0.002 \\
\hline \multicolumn{8}{|c|}{$\mathrm{Al}-\mathrm{Km}\left(\mu \mathrm{mol} \mathrm{L}{ }^{-1}\right)$} \\
\hline $\begin{array}{l}\text { Maravilha } \\
\text { ANa7007 }\end{array}$ & $\begin{array}{l}188^{\dagger} \mathrm{a} \\
180 \mathrm{~b}\end{array}$ & $\begin{array}{l}189 a \\
192 a\end{array}$ & $\begin{array}{l}192 \mathrm{a} \\
186 \mathrm{ab}\end{array}$ & $\begin{array}{l}189 a \\
192 a\end{array}$ & 0.180 & 0.021 & 0.017 \\
\hline \multicolumn{8}{|c|}{$\mathrm{Al}-\mathrm{Cmin}\left(\mu \mathrm{mol} \mathrm{L}{ }^{-1}\right)$} \\
\hline $\begin{array}{l}\text { Maravilha } \\
\text { ANa7007 }\end{array}$ & $\begin{array}{l}181^{\dagger} \mathrm{b} \\
176 \mathrm{c}\end{array}$ & $\begin{array}{l}176^{\dagger} \mathrm{c} \\
182 \mathrm{~b}\end{array}$ & $\begin{array}{l}189^{\dagger} \mathrm{a} \\
184 \mathrm{ab}\end{array}$ & $\begin{array}{l}186 a \\
187 a\end{array}$ & 0.344 & $<0.001$ & 0.002 \\
\hline
\end{tabular}

\footnotetext{
$\dagger$ Significant difference between the upland rice cultivars under the same Si and Al supply condition; mean values followed by the same letters in the rows are not significantly different at $P \leq 0.05$ according to the LSD test

(1) $\mathrm{C}$, cultivar; $\mathrm{Si}-\mathrm{Al}$, $\mathrm{Si}$ and $\mathrm{Al}$ supply conditions; $\mathrm{C} \times \mathrm{Si}-\mathrm{Al}$, interactions of cultivar $\times \mathrm{Si}$ and $\mathrm{Al}$ supply conditions
}

the cultivar Maravilha, demonstrating that upland rice cultivars that are tolerant to $\mathrm{Al}$ (such as ANa7007) continue to produce fine roots even under conditions of Al toxicity. Although Si did not mitigate the toxic effects of $\mathrm{Al}$ on root growth in the upland rice plants in this study, research has shown that Si may increase root growth under conditions of $\mathrm{Al}$ toxicity in rice plants (Rahman et al. 1998; Giongo and Bohnen 2011; Singh et al. 2011) and corn (Wang et al. 2004), and it may even decrease the root diameter of peanut plants grown under Al stress (Shen et al. 2014).

The results demonstrate that the cultivar ANa7007 produced greater quantities of fine roots when grown in the presence of $\mathrm{Si}$ without $\mathrm{Al}$. Si is known to have a more pronounced effect on plants under stress (Ma and Takahashi 2002), and it primarily accumulates in the plant shoots, where it exerts its effect (Ma and Yamaji 2006). Moreover, the effects of $\mathrm{Si}$ on root growth are poorly understood; however, our results indicate that even in the absence of abiotic stress, Si may have a beneficial influence on the root growth of upland rice plants. The results also demonstrate that in the cultivar
Maravilha (Al susceptible), the $\mathrm{Al}$ supply promoted greater damage to the root system, thereby causing an increase in the length of thick roots. Thicker roots show a reduced capacity for water and nutrient uptake from the soil compared with medium and fine roots (Taiz and Zeiger 2013).

The finding of greater Si accumulation in the shoots even in the treatments that received $\mathrm{Al}$ indicates that $\mathrm{Al}$ did not decrease the transport of Si to plant shoots. In the whole plant, the observation that more Si accumulated in the treatments that included $\mathrm{Si}$, regardless of the presence of $\mathrm{Al}$, demonstrates that $\mathrm{Al}$ did not alter the uptake of Si or significantly affect the quantity of Si that accumulated in the shoots and the whole plant (Table 2).

The finding that the decrease in the shoot $\mathrm{Al}$ concentration was mediated by Si demonstrates that the presence of $\mathrm{Si}$ in the solution decreased $\mathrm{Al}$ translocation to the shoots, which contributed to the increase in plant shoot DM compared with that in the Al treatment (Table 1). According to Cocker et al. (1998) and Vázquez et al. (1999), the Si added to the solution may interact with $\mathrm{Al}$, make it non-toxic to the plant and 
decrease Al translocation to the shoot, thereby alleviating its toxicity in the plant shoots, which was confirmed in our study.

The increased concentration of $\mathrm{Al}$ in the roots of tolerant cultivars (e.g., ANa7007) is a strategy exhibited by the plant to inactivate or store the $\mathrm{Al}$ in a non-toxic form in the roots and to translocate less Al to the shoots, thereby decreasing the Al toxicity to the plant (Kochian 1995; Matsumoto 2000; Barceló and Poschenrieder 2002; Ma and Furukawa 2003). The presence of Si in the solution did not reduce the root $\mathrm{Al}$ concentration and accumulation in the treatments in which Al was present, and similar results were observed for the root DM (Tables 1 and 2).

In the whole plant, the Si decreased $\mathrm{Al}$ accumulation only in the susceptible cultivar, indicating that the Siinduced mitigation of $\mathrm{Al}$ toxicity was more evident in the Al-susceptible cultivar and that the main effect of $\mathrm{Si}$ was related to a reduction of Al transport and shoot accumulation (Singh et al. 2011; Shen et al. 2014).

The higher Si uptake observed in the treatments without $\mathrm{Al}$ demonstrates a lower capacity for Si uptake in the plants grown under $\mathrm{Al}$ toxicity.

Our findings indicate that $\mathrm{Al}$ decreased Si uptake by negatively affecting root morphology and physiology (Tables 1 and 3). Aluminum toxicity alters the plasma membrane permeability (Kochian 1995; Ahn et al. 2001; Yamamoto et al. 2001), thereby modifying the fluidity of lipids because of the electrostatic connection, which is induced by $\mathrm{Al}$ in the polar regions of phosphatidylcholine (Rengel 1996; Justino et al. 2006). Because Al toxicity affects the root growth, it also affects the nutrient uptake. These effects were also observed in sorghum plants in which Al modified the kinetic constants of root $\mathrm{P}$ uptake, thereby decreasing the uptake of P (Pereira et al. 2008).

The reduced Imax values caused by Al must be related to damage to the $\mathrm{Si}$ transporters and less activity of the genes responsible for $\mathrm{Si}$ signaling (Lsi1) (Ma et al. 2004, 2006, 2007) because these genes act in the root exodermis and endoderm, where $\mathrm{Al}$ produces the most damage. Because rice is a $\mathrm{Si}-$ accumulating plant, Si plays an important role in its growth (Ma and Takahashi 2002). Thus, the higher Si Imax value in the control plants indicates that plants grown without $\mathrm{Si}$ that were subsequently supplied with this element (Table 3) increase their Imax to maintain their internal balance of $\mathrm{Si}$.
Both cultivars experienced increased $\mathrm{Si} \mathrm{Km}$ and $\mathrm{Cmin}$ values in the presence of $\mathrm{Al}$, demonstrating that $\mathrm{Al}$ in the solution decreased the affinity of the Si transporter system in the roots $(\mathrm{Km})$ as well as the plant $\mathrm{Si}$ uptake capacity, since in the presence of $\mathrm{Al}$ in the solution, the plants ceased the Si uptake despite high $\mathrm{Si}$ availability in the solution (>Cmin) (Table 3 ). This result was likely caused by Al-induced structural damage to the roots (Kochian et al. 2004). Moreover, these findings demonstrate that for a plant to maintain $\mathrm{Si}$ uptake in the presence of $\mathrm{Al}$, the $\mathrm{Si}$ availability in the solution must be approximately 6.6 times higher than in the absence of $\mathrm{Al}$, since in the treatments without $\mathrm{Al}$ (control and $+\mathrm{Si}$ ), the $\mathrm{Cmin}$ of both cultivars averaged 4.8, whereas in the treatments with $\mathrm{Al}(+\mathrm{Al}$ and $+\mathrm{Si}+$ $\mathrm{Al}$ ) the Cmin values averaged 31.8 (Table 3 ). The Alinduced structural damage to the roots also negatively affects water and nutrient uptake by the plants (Mistro et al. 2001; Mendonça et al. 2003), as observed in this study, in which $\mathrm{Al}$ increased the Si Cmin, thereby reducing the plants Si uptake capacity.

The finding that the Al-tolerant cultivar showed lower Si $\mathrm{Km}$ and $\mathrm{Cmin}$ values in the treatments involving $\mathrm{Si}$ than in the Al-only treatments indicates that in this cultivar, the supply of $\mathrm{Si}$ in the solution alleviated $\mathrm{Al}$ toxicity in the roots, maintained a higher Si transporter affinity and supported the Si uptake capacity.

Aluminum uptake was irregular in both cultivars (Fig. 1c and d), indicating that during growth, the upland rice plants utilize protection mechanisms to prevent the uptake of $\mathrm{Al}$ from the nutrient solution (Kochian et al. 2005). The rate of Al uptake from the solution was low in the first $10 \mathrm{~h}$ and then remained relatively constant; therefore, the rate of $\mathrm{Al}$ depletion from the solution was always lower in the treatments with Al because these treatments promoted restricted root growth.

Our results indicate that in both cultivars, the supply of Si did not reduce the Al uptake rate (Imax) in the plants, although Si mediated a significant reduction of Al transport to the plant shoots in the Al-susceptible cultivar (Maravilha), thereby promoting lower $\mathrm{Al}$ accumulation in the shoots and the whole plant (Tables 2 and 3 ). In the literature, two hypotheses have been postulated regarding the mediation of $\mathrm{Al}$ toxicity by $\mathrm{Si}$. The first is related to interactions that occur inside the plant (Hodson and Evans 1995; Corrales et al. 1997; Cocker et al. 1998; Neumam and Nieden 2001; Kidd et al. 2001; Liang et al. 2007), such as that shown in this work. The second hypothesis is related to interactions between $\mathrm{Si}$ 
and $\mathrm{Al}$ in the soil solution (Ma et al. 1997) and the complexing of $\mathrm{Al}$ into non-toxic forms, which was not observed in this study because the Al-tolerant cultivar accumulated the same quantities of $\mathrm{Al}$ in the treatments with and without $\mathrm{Si}$ (Table 2).

The lower values of $\mathrm{Al} \mathrm{Km}$ and Cmin observed in the cultivar ANa7007 than in the cultivar Maravilha in the control treatment show that although the Al-tolerant cultivar may exhibit a higher efficiency of Al transporters in its roots (lower $\mathrm{Km}$ and $\mathrm{Cmin}$ ), it has a low $\mathrm{Al}$ Imax, indicating that the $\mathrm{Al}$ transport system in the roots is efficient but that the $\mathrm{Al}$ uptake rate is low due to the lower number of specific transporters for Al uptake in the roots (Table 3), resulting in a slight $\mathrm{Al}$ depletion in the nutrient solution (Fig. 1). In rice plants, these $\mathrm{Al}$ transporters in the root system have been identified (e.g., Nrat1 - Nramp aluminum transporter), and it has been observed that in root tips of Al-tolerant rice accessions, the level of Nrat1 expression and the levels of $\mathrm{Al}$ in the cell sap were higher, whereas the Al levels in the cell wall were lower (Li et al. 2014) as well as the reports of Simões et al. (2012) and Xia et al. (2010). Negishi et al. (2012) reported that the expression level of PM Al transporter (PALT1) and the vacuolar Al transporter (VALT) regulate $\mathrm{Al}$ tolerance and sensitivity in Arabidopsis. Those findings obtained led to the suggestion that Nratl plays a role in partitioning Al between the rice root cell wall and symplasm as an $\mathrm{Al}$ resistance mechanism (Li et al. 2014).

The reduced $\mathrm{Al} \mathrm{Cmin}$ in the $\mathrm{Al}$ treatments indicates that this ion toxicity reduced the root growth and also reduced the root uptake surface area, which also reduced the capacity of the plants to take up Al from the solution.

\section{Conclusions}

Aluminum decreased plant growth and the Si uptake capacity by decreasing the root growth and Si transport system efficiency in the upland rice roots ( $>\mathrm{Km}$ and $>$ Cmin). The addition of Si mitigated the Al toxicity in upland rice plants by decreasing the $\mathrm{Al}$ transport to the plant shoots, although it did not reduce the Al uptake rate (Imax). The addition of Si increased the growth of the upland rice plant shoots grown in the presence of $\mathrm{Al}$ but did not influence the root growth. The alleviation of $\mathrm{Al}$ toxicity by $\mathrm{Si}$ was more evident in the susceptible cultivar Maravilha.
Acknowledgements We are grateful to the São Paulo Research Foundation (FAPESP) for supporting this research (grant \#2011/ 22182-8) and for providing a scholarship to the first author (grant \#2011/09283-0) and to The National Council for Scientific and Technological Development $(\mathrm{CNPq})$ for providing a research grant to the second author. We would also like to thank the Federal Institute Goiano for providing a research grant to the third author and for supporting this study.

\section{Compliance with ethical standards}

Conflict of interest The authors affirm that there are no conflicts of interest regarding this manuscript.

\section{References}

Aftab T, Khan MMA, Idrees M, Moinuddin NM (2010) Effects of aluminium exposures on growth, photosynthetic efficiency, lipid peroxidation, antioxidant enzymes and artemisinin content of Artemisia Annua L. J Phytology 2:23-37

Ahn SJ, Sivaguru M, Osawa H, Chung GC, Matsumoto H (2001) Aluminum inhibits the $\mathrm{H}^{+}$-ATPase activity by permanently altering the plasma membrane surface potentials in squash roots. Plant Physiol 126:1381-1390

Ali B, Hasan SA, Hayat S, Hayat Q, Yadav S, Fariduddin Q, Ahmad A (2008) A role for brassinosteroids in the amelioration of aluminium stress through antioxidant system in mung bean (Vigna radiata L. Wilczek). Environ Exp Bot 62:153-159. https://doi.org/10.1016/j.envexpbot.2007.07.014

Alvarez I, Reynaldo OS, Testillano P, Risueño C, Arias M (2012) Morphological and cellular changes in rice roots (Oryza sativa L.) caused by Al stress. Bot Stud 53:67-73

Barber SA (1984) Soil nutrient bioavailability: a mechanistic approach. John Wiley, New York

Barceló J, Poschenrieder C (2002) Fast root growth responses, root exudates and internal detoxification as clues to the mechanisms of aluminum toxicity and resistance. Environ Exp Bot 48:75-92. https://doi.org/10.1016/S0098-8472(02)00013-8

Budikova S, Durcekova K (2004) Aluminium accumulation in roots of Al-sensitive barley cultivar changes root cell structure and induces callose synthesis. Biologia 59:215-220

Claassen N, Barber SAA (1974) Method for characterizing the relation between nutrient concentration and flux into roots of intact plants. Plant Physiol 54:564-568. https://doi.org/10.1104/pp.54.4.564

Clarkson DT (1965) The effect of aluminium and some other trivalent metal cations on cell division in the root apices of Allium cepa. Ann Bot 29:309-315. https://doi.org/10.1093/oxfordjournals.aob.a083953

Cocker KM, Evans DE, Hodson MJ (1998) The amelioration of aluminium toxicity by silicon in higher plants: solution chemistry or an in planta mechanism. Physiol Plant 104:608-614. https://doi.org/10.1034/j.1399-3054.1998.1040413.x

Corrales I, Poschenrieder C, Barceló J (1997) Influence of silicon pretreatment on aluminum toxicity in maize roots. Plant Soil 190:203-209. https://doi.org/10.1023/A:1004209828791 
Doncheva S, Amenós M, Poschenrieder C, Barceló J (2005) Root cell patterning: a primary target for aluminium toxicity in maize. J Exp Bot 56:1213-1220. https://doi.org/10.1093/jxb/eri115

Elliott CL, Snyder GH (1991) Autoclave-induced digestion for the colorimetric determination of silicon in rice straw. J Agric Food Chem 39:1118-1119. https://doi.org/10.1021/jf00006a024

Freitas LB, Fernandes DM, Pivetta LA, Maia SCMM (2016) Tolerance of upland rice cultivars to aluminum and acidic pH. Rev Bras Eng Agríc Ambient 20:886-614. https://doi. org/10.1590/1807-1929/agriambi.v20n10p886-890

Freitas LB, Fernandes DM, Maia SCMM, Mazziero BG (2017) Aluminum in mineral nutrition of upland rice plants. Agrária 12:26-34. https://doi.org/10.5039/agraria.v12ila5414

Gaume A, Mächler F, Frossard E (2001) Aluminum resistance in two cultivars of Zea may L.: root exudation of organic acids and influence of phosphorous nutrition. Plant Soil 234:7381. https://doi.org/10.1023/A:1010535132296

Giongo V, Bohnen H (2011) Relation between aluminum and silicon in maize genotypes resistant and sensitive at aluminum toxicity. (In Portuguese, with English abstract.) Biosci J 27:348-356

Hammond KE, Evans DE, Hodson MJ (1995) Aluminum/silicon interactions in barley (Hordeum vulgare L.) seedlings. Plant Soil 173:89-95. https://doi.org/10.1007/BF00155521

Hodson MJ, Evans DE (1995) Aluminium/silicon interactions in higher plants. J Exp Bot 46:161-171. https://doi.org/10.1093 jjxb/46.2.161

Horst WJ, Kollmeier M, Schmohl N, Sivaguru M, Wang Y, Felle HH, Hedrich R, Schröder W, Staß A (2007) Significance of the root apoplast for aluminium toxicity and resistance of maize. In: Sattelmacher B, Horst WJ (eds) The apoplast of higher plants compartment of storage, transport, and reactions. Springer Verlag, Dordrecht, pp 49-66

Huang JW, Pellet DM, Papernik LA, Kochian LV (1996) Aluminum interactions with voltage-dependent calcium transport in plasma membrane vesicles isolated from roots of aluminum-sensitive and -resistant wheat cultivars. Plant Physiol 110:561-569

Justino GC, Cambraia J, Oliva MA, Olveira JA (2006) Uptake and reduction of nitrate in two rice cultivars in the presence of aluminum. (In Portuguese, with English abstract.) Pesq Agrop Brasileira 41:1285-1290. https://doi.org/10.1590 /S0100-204X2006000800011

Khan MS, Tawaraya K, Sekimoto K, Koyama H, Kobayashi Y, Murayama T, Chuba M, Kambayashi M, Shiono Y, Uemura M, Ishikawa S, Wagatsuma T (2009) Relative abundance of delta5-sterols in plasma membrane lipids of root-tip cells correlates with aluminum tolerance of rice. Physiol Plant 135:73-83. https://doi.org/10.1111/j.1399-3054.2008.01175.x

Kidd PS, Llugany M, Poschenrieder C, Gunsé B, Barceló J (2001) The role of root exudates in aluminum resistance and silicon induced amelioration of aluminum toxicity in three varieties of maize (Zea mays L.) J Exp Bot 52: 1339-1352. https://doi.org/10.1093/jexbot/52.359.1339

Kochian LV (1995) Cellular mechanisms of aluminum toxicity and resistance in plants. Annu Rev Plant Physiol Plant Mol Biol 46:237-260. https://doi.org/10.1146/annurev. pp.46.060195.001321
Kochian LV, Hoekenga OA, Piñeros MA (2004) How do crop plants tolerate acid soils? Mechanisms of aluminum tolerance and phosphorous efficiency. Annu Rev Plant Biol 55:459-493. https://doi.org/10.1146/annurev.arplant.55.031903.141655

Kochian LV, Piñeros MA, Hoekenga OA (2005) The physiology, genetics and molecular biology of plant aluminum resistance and toxicity. Plant Soil 274:175-195. https://doi.org/10.1007/s11104-004-1158-7

Kopittke PM, Blamey FPC, Menzies NW (2008) Toxicities of soluble $\mathrm{Al}, \mathrm{Cu}$, and $\mathrm{La}$ include ruptures to rhizodermal and root cortical cells of cowpea. Plant Soil 303:217-227. https://doi.org/10.1007/s11104-007-9500-5

Korndörfer GH, Coelho NM, Snyder GH, Myzutani CT (1999) Avaliação de métodos de extração de silício em solos cultivados com arroz de sequeiro. (In Portuguese, with English abstract.) Rev Bras Ciênc Solo 23:101-106. https://doi.org/10.1590/S0100-06831999000100013

Li Y, Yang GX, Luo LT, Ke T, Zhang JR, Li KX, He GY (2008) Aluminium sensitivity and tolerance in model and elite wheat varieties. Cereal Res Commun 36:257-267. https://doi.org/10.1556/CRC.36.2008.2.6

Li JY, Liu J, Dong D, Jia X, McCouch SR, Kochian LV (2014) Natural variation underlies alterations in Nramp aluminum transporter (NRAT1) expression and function that play a key role in rice aluminum tolerance. Proc Natl Acad Sci U S A 111:6503-6508. https://doi.org/10.1073/pnas.1318975111

Liang Y, Sun W, Zhu Y, Christie P (2007) Mechanisms of silicon-mediated alleviation of abiotic stresses in higher plants: a review. Environ Pollut 147:422-428. https://doi.org/10.1016/j.envpol.2006.06.008

Liao H, Wan H, Shaff J, Wang X, Yan X, Kochian L (2006) Phosphorus and aluminum interactions in soybean in relation to aluminum tolerance. Exudation of specific organic acids from different regions of the intact root system. Plant Physiol 141:674-684. https://doi.org/10.1104/pp.105.076497

Ma JF, Furukawa J (2003) Recent progress in the research of external Al detoxification in higher plants: a mini review. $\mathrm{J}$ Inorg Biochem 97:46-51. https://doi.org/10.1016/S01620134(03)00245-9

Ma JF, Takahashi E (2002) Soil, fertilizer, and plant silicon research in Japan. Elsevier Science, Amsterdam

Ma JF, Yamaji N (2006) Silicon uptake and accumulation in higher plants. Trends Plant Sci 11:392-397. https://doi.org/10.1016 j.tplants.2006.06.007

Ma JF, Sasaki M, Matsumoto H (1997) Al-induced inhibition of root elongation in corn, Zea mays $\mathrm{L}$. is overcome by $\mathrm{Si}$ addition. Plant Soil 188:171-176. https://doi.org/10.1023 /A:1004274223516

Ma JF, Shen R, Zhao Z, Wissuwa M, Takeuchi Y, Ebitani T, Yano M (2002) Response of rice to Al stress and identification of quantitative trait loci for Al tolerance. Plant Cell Physiol 43: 652-659. https://doi.org/10.1093/pcp/pcf081

Ma JF, Mitani N, Nagao S, Konishi S, Tamai K, Iwashita T, Yano M (2004) Characterization of the silicon uptake and molecular mapping of the silicon transporter gene in rice. Plant Physiol 136:3284-3289. https://doi.org/10.1104 /pp.104.047365

Ma JF, Tamai K, Yamaji N, Mitani N, Konishi S, Katsuhara M, Ishiguro M, Murata Y, Yano M (2006) A silicon transporter in rice. Nature 440:688-691. https://doi.org/10.1038/nature04590 
Ma JF, Yamaji N, Mitani N, Tamai K, Konishi S, Fujiwara T, Katsuhara M, Yano M (2007) An efflux transporter of silicon in rice. Nature 448:209-211. https://doi.org/10.1038/nature05964

Malavolta E, Vitti GC, Oliveira SA (1997) Evaluation of nutritional status of plants: principles and applications $2 \mathrm{rd}$ edn. (In Portuguese.) Potafos, Piracicaba

Mariano ED, Keltjens WG (2005) Long-term effects of aluminum exposure on nutrient uptake by maize genotypes differing in aluminum resistance. J Plant Nutr 28:323-333. https://doi.org/10.1081/PLN-200047625

Matsumoto H (2000) Cell biology of aluminum toxicity and tolerance in higher plants. Int Rev Cytol 200:1-46. https://doi.org/10.1016/S0074-7696(00)00001-2

Meharg AA (1993) The role of the plasmalemma in metal tolerance in angiosperms. Physiol Plant 88:191-198. https://doi.org/10.1111/j.1399-3054.1993.tb01777.x

Mendonça RJ, Cambraia J, Oliveira JA, Oliva MA (2003) Aluminum effects on the uptake and utilization of macronutrients in two rice cultivars. (In Portuguese, with English abstract.) Pesq Agrop Brasileira 38:843-846. https://doi.org/10.1590/S0100-204X2003000700008

Mistro JC, Camargo CEO, Pettinelli-Júnior A (2001) Evaluation of wheat genotypes from different origins in relation to aluminum toxicity. (In Portuguese, with English abstract.) Bragantia 60:1-9. https://doi.org/10.1590/S000687052001000300004

Morimura S, Matsumoto H (1978) Effect of aluminum on some properties and template activity of purified pea DNA. Plant Cell Physiol 19:429-436. https://doi.org/10.1093 /oxfordjournals.pcp.a075611

Negishi T, Oshima K, Hattori M, Kanai M, Mano S, Nishimura M, Yoshida K (2012) Tonoplast-and plasma membranelocalized aquaporin-family transporters in blue hydrangea sepals of aluminum hyperaccumulating plant. PLoS One 7: e4389. https://doi.org/10.1371/journal.pone.0043189

Neumam D, Nieden U (2001) Silicon and heavy metal tolerance of higher plants. Phytochemistry 56:685-692. https://doi.org/10.1016/S0031-9422(00)00472-6

Olivares E, Peña E, Marcano E, Mostacero J, Aguiar G, Benítez M, Rengifo E (2009) Aluminum accumulation and its relationship with mineral plant nutrients in 12 pteridophytes from Venezuela. Environ Exp Bot 65:132-141. https://doi.org/10.1016/j.envexpbot.2008.04.002

Panda SK, Baluska F, Matsumoto H (2009) Aluminum stress signaling in plants. Plant Signal Behav 7:592-597. https://doi.org/10.4161/psb.4.7.8903

Pereira JM, Cambraia J, Fonseca Júnior ÉM, Ribeiro C (2008) Aluminum effect on uptake, accumulation and fractionation of phosphorus in sorghum. (In Portuguese, with English abstract.) Bragantia 67:961-967. https://doi.org/10.1590/S0006-87052008000400019

Rahman MT, Kawamura K, Koyama H, Hara T (1998) Varietal differences in the growth of rice plants in response to aluminum and silicon. Soil Sci Plant Nutr 44:423-431. https://doi.org/10.1080/00380768.1998.10414464

Rangel AF, Rao IM, Horst WJ (2009) Intracellular distribution and binding state of aluminum in root apices of two common bean (Phaseolus vulgaris) genotypes in relation to Al toxicity. Physiol Plant 135:162-173. https://doi.org/10.1111/j.1399-3054.2008.01183.x
Rengel Z (1996) Uptake of aluminum by plant cells. New Phytol 134:389-406. https://doi.org/10.1111/j.1469-8137.1996. tb04356.x

Rengel Z, Zhang W (2003) Role of dynamics of intracellular calcium in aluminium-toxicity syndrome. New Phytol 159: 295-314. https://doi.org/10.1046/j.1469-8137.2003.00821.x

Ruiz HA, Fernandes Filho EI (1992). Cinética: software to estimate the Imax and $\mathrm{Km}$ constants of Michaelis-Menten equation. In: 20 Brazilian meeting of soil fertility and plant nutrition. (In Portuguese.) Piracicaba, pp 124-125

Ryder M, Gérard F, Evans DE, Hodson MJ (2003) The use of root growth and modelling data to investigate amelioration of aluminium toxicity by silicon in Picea abies seedlings. J Inorg Biochem 97:52-58. https://doi.org/10.1016/S0162-0134(03)00181-8

Sangster AG, Hodson ML (2001) Silicon and aluminium deposition in the cell wall phytoliths of gymnosperm leaves. In: Meunier JD, Colin FAA (eds) Phytoliths: applications in earth science and human history. A A Balkema, Rotterdan, pp 343-355

Shen X, Xiao X, Dong Z, Chen Y (2014) Silicon effects on antioxidative enzymes and lipid peroxidation in leaves and roots of peanut under aluminum stress. Acta Physiol Plant 36: 3063-3069. https://doi.org/10.1007/s11738-014-1676-8

Silva S, Pinto-Carnide O, Martins-Lopes P, Matos M, GuedesPinto H, Santos C (2010) Differential aluminium changes on nutrient accumulation and root differentiation in an $\mathrm{Al}$ sensitive vs. tolerant wheat. Environ Exp Bot 68:91-98. https://doi.org/10.1016/j.envexpbot.2009.10.005

Simões CC, Melo JO, Magalhaes JV, Guimarães CT (2012) Genetic and molecular mechanisms of aluminum tolerance in plants. Genet Mol Res 11:19491957. https://doi.org/10.4238/2012.July.19.14

Singh VP, Tripathi DK, Kumar D, Chauhan DK (2011) Influence of exogenous silicon addition on aluminium tolerance in rice seedlings. Biol Trace Elem Res 144: 1260-1274. https://doi.org/10.1007/s12011-011-9118-6

Tabuchi A, Matsumoto H (2001) Changes in cell-wall properties of wheat (Triticum aestivum) roots during aluminuminduced growth inhibition. Physiol Plant 112:353-358. https://doi.org/10.1034/j.1399-3054.2001.1120308.x

Taiz L, Zeiger E (2013) Plant physiology, 5rd edn. Sinauer, England

Tennant DA (1975) A test of a modified line intersect method of estimating rootlength. J Ecol 63:995-1001. https://doi.org/10.2307/2258617

Tokura AM, Furtini Neto AE, Carneiro LF, Curi N, Santos JZL, Alovisi AA (2011) Dynamics of phosphorus forms in soils with contrasting texture and mineralogy cultivated with rice. (In Portuguese, with English abstract.) Acta Sci Agron 33: 171-179. https://doi.org/10.4025/actasciagron.v33i1.1435

Vázquez MD, Poschenrieder C, Corrales I, Barceló (1999) Changes in apoplastic Al during the initial growth response to Al by roots of a resistant maize variety. Plant Physiol 119: 435-444. doi: https://doi.org/10.1104/pp.119.2.435

Vitorello VA, Capaldi FR, Stefanuto VA (2005) Recent advances in aluminium toxicity and resistance in higher plants. Braz J Plant Physiol 17:129-143. https://doi.org/10.1590/S1677-04202005000100011

Wang Y, Stass A, Horst WJ (2004) Apoplastic binding of aluminum is involved in silicon-induced amelioration of 
aluminum toxicity in maize. Plant Physiol 136:3762-3770. https://doi.org/10.1104/pp.104.045005

Xia J, Yamaji N, Kasai T, Ma JF (2010) Plasma membranelocalized transporter for aluminum in rice. Proc Natl Acad Sci U S A 107:18381-18385. https://doi.org/10.1073 /pnas.1004949107

Yamamoto Y, Hobayashi Y, Matsumoto H (2001) Lipid peroxidation is an early symptom triggered by aluminum, but not the primary cause of elongation inhibition in pea poots. Plant Physiol 125:199-208. https://doi.org/10.1104/pp.125.1.199

Yang JL, Li YY, Zhang YJ, Zhang SS, Wu YR, Wu P, Zheng SJ (2008) Cell wall polysaccharides are specifically involved in the exclusion of aluminum from the rice root apex. Plant Physiol 146:602-611. https://doi.org/10.1104/pp.107.111989

Yang JL, Zhu XF, Peng YZ, Zheng C, Li GX, Liu Y, Shi YZ, Zheng SJ (2011) Cell wall hemicelluloses contributes significantly to aluminum adsorption and root growth in Arabidopsis. Plant Physiol 155:1885-1892. https://doi.org/10.1104/pp.111.172221

Yi M, Yi H, Li H, Wu L (2010) Aluminum induces chromosome aberrations, micronuclei, and cell cycle dysfunction in root cells of Vicia faba. Environ Toxicol 25:124-129. https://doi.org/10.1002/tox.20482

Zhang XB, Liu P, Yang YS, Xu GD (2007) Effect of Al in soil on photosynthesis and related morphological and physiological characteristics of two soybean genotypes. Bot Stud 48:435-444

Zheng SJ, Yang JL (2005) Target sites of aluminum phytotoxicity. Biol Plant 49:321-331. https://doi.org/10.1007/s10535-0050001-1

Zobel RW, Kinraide TB, Baligar VC (2007) Fine root diameters can change in response to changes in nutrient concentrations. Plant Soil 297:243-254. https://doi.org/10.1007/s11104-0079341-2 